Navab, F., and Asatoor, A. M. (1970). Gut, 11, 373.

Newey, H., and Smyth, D. H. (1959). Fournal of Physiology, 145, 48. Newey, H., and Smyth, D. H. (1960). Fournal of Physiology, 152, 367.
Newey, H., and Smyth, D. H. (1962). Fournal of Physiology, 164, 527.

Payne, J. W. (1968) Fournal of Biological Chemistry 243, 3395.

Peters, T. J., Linnell, J. C., Matthews, D. M., and Hoffbrand, A. V. (1971)

Peters, T. J., Linnell, J. C., Matthews, D. M.
British fournal of Haematology, 20, 299.

British fournal of Haematolog
Sadikali, F. (1971). Gut, 12, 276.

Smith, A. D. M. (1961). Lancet, 1, 1001.

Tarlow, M. J., et al. (1970). Clinical Science, 39, 18P.
Toohey, J. I., and Barker, H. A. (1961). Fournal of Biological Chemistry, Wilson, 560 .

(965). Clinical Science, 29, 505.

ilson, J., Linnell, J. C., and Matthews, D. M. (1971). Lancet, 1, 259.

Wilson, J., and Matthews, D. M. (1966). Clinical Science, 31, 1. Winitz, M., Seedman, D. A., and Graff, J. (1970). American fournal

Wiseman, G. (1951). fournal of Physiology, 114, 7P.

Wiseman, G. (1968). In Handbook of Physiology, Section 6, vol. 3, ed. C. F. Code, p. 1277. Washington D.C., American Physiological Society.

\title{
Method of Removing Abnormal Protein Rapidly from Patients with Malignant Paraproteinaemias
}

\author{
R. POWLES， C. SMITH， J. KOHN， G. HAMILTON FAIRLEY
}

British Medical fournal, 1971, 3, 664-667

\section{Summary}

On 48 occasions large quantities of abnormal protein were removed from the blood of 11 patients with malignant paraproteinaemias (plasmacytomas) by exchanging their plasma with reconstituted blood bank plasma. The IBM continuous flow blood cell separator was used to exchange the plasma, a procedure that is safe, very rapid, and with clinical benefits which are much better than can be obtained by conventional plasmapheresis. In addition, the constituents of reconstituted plasma correct deficiencies in normal immunoglobulins found in these patients. Clearly for the management of some patients with paraproteinaemia a cell separator is essential.

\section{Introduction}

The therapeutic benefits of plasmapheresis in the management of patients with malignant paraproteinaemia are well established (Schwab and Fahey, 1960; Conway and Miles Walker, 1962; Skoog et al., 1962; Lawson et al., 1968), but such procedures are associated with certain disadvantages. They are time-consuming, technically difficult, and though removing abnormal protein also deplete the patients of normal proteins. Godal and Borchgrevink (1965) described the case of a patient with macroglobulinaemia developing pneumonia after plasmapheresis attributed to the removal of normal immunoglobulins, and Solomon and Fahey (1963), in a similar situation, noticed a reduction in serum albumin after the removal of 1 litre of plasma daily for four days, which was sufficient to cause ankle oedema.

The purpose of this paper is to show that the NCl IBM cell separator overcomes these difficulties. The separator exchanges the patient's plasma for reconstituted freeze-dried plasma, and large quantities of abnormal protein are removed not only quickly and easily but also with the special advantage of replacing the patient's own deficiencies of albumin and normal immunoglobulins.

\footnotetext{
Department of Clinical Research, Institute of Cancer Research, Royal Marsden Hospital, Sutton, Surrey R. POWLES, B.SC., M.R.C.P., Research Fellow C. R. SMITH, A.I.M.L.T., Medical Laboratory Assistan G. HAMILTON FAIRLEY, D.M., F.R.C.P., Consultant Physician

Queen Mary's Hospital, Roehampton, London S.W. 15 J. KOHN, D.C.P., F.R.C.PATH., Senior Consultant Pathologist
}

\section{Materials and Methods}

NCl IBM Cell Separator.-This is a machine designed for the collection of leucocytes from peripheral blood (Buckner et al., 1969; Powles et al., 1971). However, it can be used for plasma exchange. In the management of patients with paraproteinaemia the patient's plasma is exchanged for freezedried plasma. Blood is continuously drawn from the antecubital vein in one arm and separated into cells and plasma in a centrifuge bowl. The blood is exposed to a high gravitational force $(100 \mathrm{~g})$ so that platelets are removed from the patient's plasma before exchange occurs, and these platelets are returned to the patient with the other cells; this is important because the platelets in freeze-dried plasma are destroyed. The patient's plasma is then removed in exchange for reconstituted normal freeze-dried plasma which is mixed with the patient's separated cells and returned to a vein in another limb. Consequently whole blood with the abnormal protein greatly reduced is therefore returned to the patient. A dual-channelled auxiliary pump and special tubing sets (Avon Medical Ltd.) ensure that the volume of the patient's plasma removed equals the volume of reconstituted freeze-dried plasma returned to the patient.

If the patient is anaemic the donor red cells may be exchanged for the patient's plasma, correcting the anaemia without altering the total blood volume. About 2.5 litres of whole blood is processed every hour, and patients are treated for up to seven hours in a single session without undue discomfort. Heparin is used as an anticoagulant, the patient receiving 3,000 units intravenously before treatment starts and thereafter continuously 2,000 units every hour. Particular care is needed if the abnormal protein is a cryoglobulin. The centrifuge bowl is kept at about $33^{\circ} \mathrm{C}$ by means of radiant heaters, and extracorporeal fluids-that is, blood, plasma, and heparinized saline-are kept at $40^{\circ} \mathrm{C}$.

Biochemical Estimations.-All biochemical estimations were performed on fresh serum collected and separated at $37^{\circ} \mathrm{C}$ and stored at $-20^{\circ} \mathrm{C}$. Viscosity was measured by forcing a constant volume of plasma at $37^{\circ} \mathrm{C}$ through a $1-\mathrm{mm}$ aperture at constant pressure. The results were expressed in seconds and were compared with that of donor plasma.

\section{Results}

Eleven patients with paraproteinaemia were treated with plasma exchange on 50 occasions over a period of two years.

\section{CLINICAL IMPROVEMENT}

The clinical indications for plasma exchange in the patients studied are shown in Table $I$ and the results are as follows: 
TABLE I-Clinical Indications for Plasma Exchange

\begin{tabular}{|c|c|c|c|c|c|c|}
\hline Case No. & Sex & Age & Type & Indication for Plasma Exchange & $\begin{array}{c}\text { No. of } \\
\text { Plasma } \\
\text { Exchanges }\end{array}$ & $\begin{array}{l}\text { Total Volume } \\
\text { Plasma } \\
\text { Exchanges (1.) }\end{array}$ \\
\hline $\begin{array}{l}1 \\
2 \\
3 \\
4 \\
5\end{array}$ & $\begin{array}{l}\text { M. } \\
\text { F. } \\
\text { M. } \\
\text { F. }\end{array}$ & $\begin{array}{l}57 \\
67 \\
60 \\
30 \\
65\end{array}$ & $\begin{array}{l}\text { IgG(K) } \\
\text { IgG }(\mathrm{K}) \text { cryoglobulins } \\
\text { Iga }+(\mathrm{BJ}) \\
\text { IgG } \\
\text { IgG }\end{array}$ & $\begin{array}{l}\quad \text { Multiple Myeloma } \\
\text { Coma. Failed chemotherapy } \\
\text { Leg ulcers. Failed chemotherapy } \\
\text { Renal failure. Failed chemotherapy } \\
\text { Intractable gastrointestinal haemorrhage. Untreated } \\
\text { Multiple thromboemboli. Gangrene left arm. Untreated }\end{array}$ & $\begin{array}{r}15 \\
2 \\
2 \\
1 \\
3\end{array}$ & $\begin{array}{l}80 \\
6 \cdot 5 \\
10 \cdot 9 \\
5 \cdot 0 \\
5 \cdot 0\end{array}$ \\
\hline $\begin{array}{r}6 \\
7 \\
8 \\
9 \\
10\end{array}$ & $\begin{array}{l}\text { M. } \\
\text { M. } \\
\text { M. } \\
\text { F. }\end{array}$ & $\begin{array}{l}60 \\
55 \\
47 \\
79 \\
65\end{array}$ & $\begin{array}{l}\text { IgM cryoglobulins } \\
\text { IgM } \\
\text { IgM cryoglobulins } \\
\text { IgM } \\
\text { IgM }\end{array}$ & $\begin{array}{l}\text { Macroglobulinaemia } \\
\text { Confusion. Poor response to chemotherapy } \\
\text { Intractable nasopharyngeal haemorrhage. Failed chemotherapy } \\
\text { Confusion. Haemorrhage. Rapidly rising plasma viscosity. Untreated } \\
\text { Gross fundal changes and decreased visual acuity. Epistaxis. Untreated } \\
\text { Gross fundal changes and decreased visual acuity. Poor response to }\end{array}$ & $\begin{array}{r}3 \\
19 \\
2 \\
1 \\
1\end{array}$ & $\begin{aligned} 9 \cdot 0 \\
100 \\
11 \cdot 8 \\
2 \cdot 3 \\
3 \cdot 0\end{aligned}$ \\
\hline 11 & M. & 76 & $\operatorname{IgM}$ & $\begin{array}{l}\text { Preparation for herniorrhaphy. Mental Confusion. Poor response to } \\
\text { chemotherapy }\end{array}$ & 1 & $3 \cdot 0$ \\
\hline
\end{tabular}

Neurological.-The typical effect of plasma exchange on neurological symptoms is shown in the following case.

A man aged 57 with multiple myeloma had become unresponsive to chemotherapy (Case 1). He was in a coma attributable to raised serum viscosity. After $4 \mathrm{l}$. of plasma had been exchanged he regained consciousness and after 71 . had been exchanged he could converse normally. Following subsequent plasma exchanges, about every three weeks, he always noticed increased alertness. Failure to concentrate at work first heralded the increase in viscosity requiring further plasma exchange. The viscosity of the plasma would rise only when the serum protein content was very high and tolerance to this raised viscosity was poor with severe symptoms developing extremely quickly. He would pass from a normal state into coma in three days. He died after one year of treatment, and necropsy showed cerebral arteriosclerosis but no other cerebral lesions.

Five other patients had similar but less severe neurological symptoms and all responded well to plasma exchange.

Retinal Changes.-All 11 patients included in the study had engorged retinal veins and five of them had exudates and haemorrhages. These haemorrhages and exudates always improved within one week of treatment. The engorgement of the veins became less within 24 hours of plasma exchange. In the two patients with impaired visual acuity there was noticeable improvement in vision after treatment, particularly for near vision.

Haemorrhagic Tendencies.-Four patients were treated because of intractable nasopharyngeal haemorrhage. One of these (Case 4) also had gastrointestinal haemorrhage from a duodenal ulcer. In all instances bleeding ceased before completion of the plasma exchange, despite the patient being anticoagulated. In one patient (Case 1) severe epistaxis had been continuous for two weeks before treatment. The success of plasma exchange in controlling haemorrhagic tendencies suggests a use for it as a preoperative preparation of patients with paraproteinaemia. An example was a 79-year-old man with macroglobulinaemia (Case 9) who required bilateral herniorrhaphy. After a 3-1. plasma exchange the operation was performed without haemorrhagic complications and yet 24 hours previously severe bruising occurred even after venepuncture.

Emergency Plasma Exchange.-Three patients (Cases 4, 5, and 8 ) were treated as emergencies with plasma exchange before chemotherapy shortly after diagnosis of their diseases (Table II). The amount of abnormal protein in these three patients was so high and increasing so rapidly that they would probably have died before chemotherapy could control their disease. All three patients had their symptoms rapidly relieved by massive plasma exchanges thus allowing time for chemotherapeutic control.

\section{BIOCHEMICAL CHANGES AFTER PLASMA EXCHANGE}

The effect of the removal of abnormal protein on plasma viscosity, level of abnormal protein, and normal plasma proteins was ascertained.
Plasma Viscosity.-The changes of plasma viscosity (and plasma protein content) during a typical plasma exchange in a 47-year-old man with macroglobulinaemia (Case 8) are shown in the Chart. The plasma viscosity (and plasma protein content) was grossly raised before treatment and not until

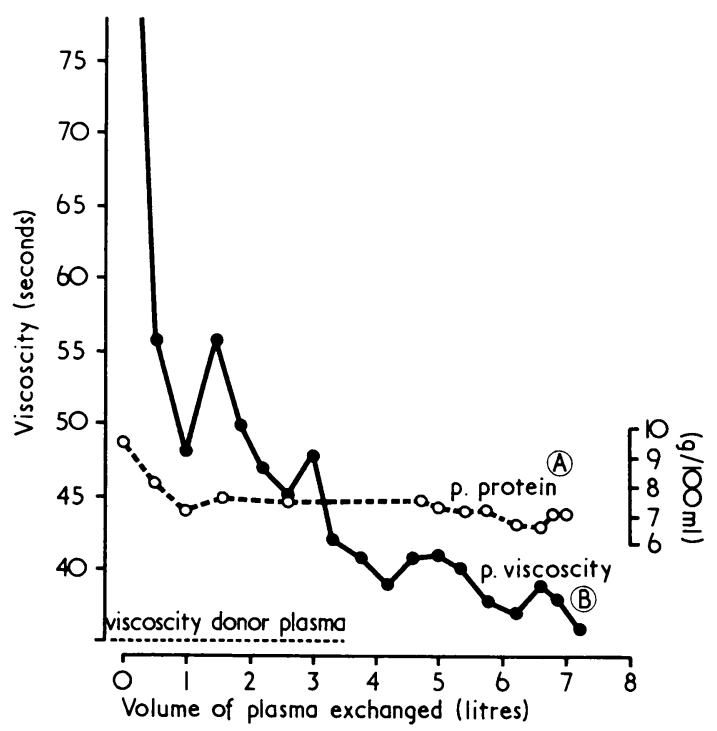

The changes in plasma viscosity (B) relative to donor plasma in a 47-year-old man with macroglobulinaemia (Case 8) during the course of a 6.8-1. plasma exchange. The duration of the exchange was six-and-a-half hours during which time $217 \mathrm{~g}$ of abnormal protein was removed. The changes occurring in plasma protein content $(A)$ are also shown.

nearly 71 . of plasma had been exchanged did the viscosity approximate to normal levels. In all patients with the viscosity syndrome plasma exchanges of this volume were required for maximum benefit.

Level of Abnormal Protein.-The changes in abnormal protein content in the serum of six patients subjected to plasma exchange on 17 occasions are shown in Table II. In all instances the amount of abnormal protein in the plasma was greatly reduced. The total amount of abnormal protein removed in these patients was always large-for example, a 6.5-1. plasma exchange removed $520 \mathrm{~g}$ of abnormal protein from a patient with multiple myeloma (Case 1) in six hours.

Normal Plasma Proteins.-Changes occurring in serum albumin during plasma exchanges were studied in four patients on 11 occasions (Table III). On all but two occasions the serum albumin was higher on completion of plasma exchange. Similar increases were seen with the normal immunoglobulins (Table II) which are usually reduced in patients with paraproteinaemia. These rises are due to albumin and immunoglobulins present in reconstituted freeze-dried plasma. 
TABlE II-Changes in Plasma Proteins on Patients with Paraproteinaemia after Plasma Exchange

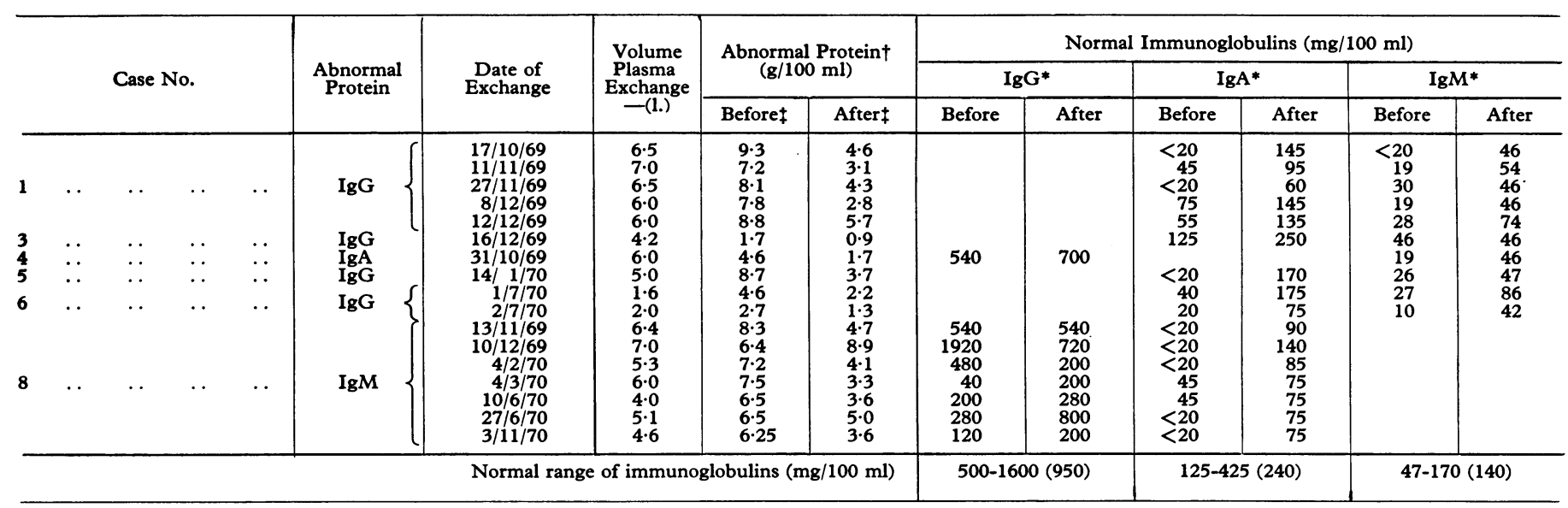

* Measured by gel diffusion (Mancini single radial immunodiffusion).

Measured by cellulose acetate electrophoresis and quantitative scanning.

$\ddagger$ Before and after plasma exchange.

TABLE III-Changes in Serum Albumin in Four Patients Treated with Plasma Exchange

\begin{tabular}{|c|c|c|c|c|c|c|c|c|}
\hline & \multirow{2}{*}{\multicolumn{6}{|c|}{ Case No. }} & \multicolumn{2}{|c|}{ Albumin $(\mathrm{g} / 100 \mathrm{ml})^{*}$} \\
\hline & & & & & & & \multirow{2}{*}{$\begin{array}{c}\text { Before } \\
\begin{array}{c}3 \cdot 3 \\
2 \cdot 2\end{array}\end{array}$} & \multirow{2}{*}{$\begin{array}{c}\text { After } \\
3.6 \\
2 \cdot 4\end{array}$} \\
\hline 2 & . & . & $\cdots$ & . & . & & & \\
\hline 6 & . & . & $\cdots$ & . & . & & $\begin{array}{l}4.3 \\
3.5\end{array}$ & $\begin{array}{l}3.3 \\
3.7\end{array}$ \\
\hline 7 & $\cdots$ & $\cdots$ & $\cdots$ & . & . & $\cdots$ & $\begin{array}{l}3 \cdot 0 \\
2 \cdot 0 \\
2 \cdot 2 \\
3 \cdot 1 \\
2 \cdot 0 \\
2 \cdot 1\end{array}$ & $\begin{array}{l}2 \cdot 7 \\
2 \cdot 7 \\
2 \cdot 7 \\
3 \cdot 4 \\
2 \cdot 5 \\
3 \cdot 1\end{array}$ \\
\hline 9 & . & . & . & . & . & . & $4 \cdot 6$ & $5 \cdot 6$ \\
\hline
\end{tabular}

* Measured by celloluse acetate electrophoresis and elution

\section{Electrolyte Changes during Plasma Exchanges}

Electrolyte concentrations in the plasma of a 60-year-old uraemic patient (Case 3) during the course of a 5.9-1. plasma exchange are shown in Table IV. The serum electrolytes remained within the normal physiological range and the patient was symptomless during four hours of treatment. The blood urea, which was raised from the start, did not alter significantly.

Particular attention is paid to the serum calcium during plasma exchange because freeze-dried plasma contains calcium in an insoluble form. Two instances of symptoms suggestive of reduced serum ionized calcium have occurred. One patient (Case 5) developed perioral tingling after 1.5 1 . of plasma had been exchanged; this responded rapidly to an intravenous injection of $500 \mathrm{mg}$ of calcium gluconate. Unfortun- ately values for ionized calcium in the serum were not available but total serum calcium values were normal. Changes in serum ionized calcium may be important after changes in the total plasma protein. The second incident occurred in a patient who developed pulsus bigeminus, severe hypotension, and perioral tingling after $1.5 \mathrm{l}$. of plasma had been exchanged. Intravenous calcium gluconate was given and after 20 minutes the patient fully recovered. The electrocardiogram showed no evidence of acute myocardial damage. Serum total calcium levels were found to be between $7 \cdot 8-9 \cdot 7 \mathrm{mg} / 100 \mathrm{ml}$.

All patients now have continuous electrocardiographic monitoring during plasma exchange and there have been no instances of changes attributable to hypocalcaemia.

\section{Removal of Cryoglobulins}

A woman of 67 with myelomatosis (Case 2) and cryoglobulinaemia had multiple painful necrotic microinfarcts on both legs. After only $1.5 \mathrm{l}$. of plasma had been exchanged the plasma in the machine gelled in spite of correct temperature control; however, even this aborted procedure removed sufficient cryoglobulin to allow 4.21 . of plasma to be exchanged two weeks later without mishap. During the following three weeks the lesions on her legs became less painful and healed to an extent not seen for many months previously. Two other patients with cryoglobulins have been treated on five occasions with similar improvement in symptoms.

\section{RATE OF REMOVAL OF ABNORMAL PROTEIN}

A 55-year-old man with macroglobulinaemia (Case 7) had 4 1. of plasma removed by conventional plasmapheresis over

TABLE IV-Effect on Blood Chemistry of Plasma Exchange of $5.9 l$.

\begin{tabular}{|c|c|c|c|c|c|c|c|c|c|c|c|c|}
\hline \multirow{2}{*}{ Fluid Exchanged } & \multirow{2}{*}{\multicolumn{2}{|c|}{$\begin{array}{l}\text { Volume } \\
\text { Exchanged (1.) }\end{array}$}} & Prot. & Alb. & $\mathrm{Ca}^{++}$ & $\mathrm{PO}_{4}$ & Uric & Urea & $\mathrm{Na}$ & $\mathrm{K}$ & $\mathrm{Cl}$ & $\mathrm{HCO}_{3}$ \\
\hline & & & $\mathrm{g} / 100 \mathrm{ml}$ & $\mathrm{g} / 100 \mathrm{ml}$ & $\mathrm{mg} / 100 \mathrm{ml}$ & $\mathrm{mg} / 100 \mathrm{ml}$ & $\mathrm{mg} / 100 \mathrm{ml}$ & $\mathrm{mg} / 100 \mathrm{ml}$ & $\mathrm{mEq} / \mathrm{l}$. & $\mathrm{mEq} / \mathrm{l}$. & $\mathrm{mE} / \mathrm{q} \mathbf{l}$ & $\mathrm{mEq} / \mathrm{l}$. \\
\hline Hartmann's solution .. & $\begin{array}{l}\text { Befor } \\
0 \\
0.4 \\
0.8\end{array}$ & $\frac{1}{2}$ & $\begin{array}{l}8.1 \\
6.8 \\
6.9 \\
6.6\end{array}$ & $\begin{array}{l}2 \cdot 4 \\
2 \cdot 1 \\
2.0 \\
2 \cdot 0\end{array}$ & $\begin{array}{r}10.3 \\
9.2 \\
9.4 \\
9.2\end{array}$ & $\begin{array}{l}4.1 \\
3.5 \\
3.6 \\
3.5\end{array}$ & $\begin{array}{l}5.6 \\
5.2 \\
5.4 \\
5.2\end{array}$ & $\begin{array}{l}195 \\
175 \\
180 \\
175\end{array}$ & $\begin{array}{l}136 \\
134 \\
133 \\
134\end{array}$ & $\begin{array}{l}4.3 \\
3.8 \\
4.0 \\
4.0\end{array}$ & $\begin{array}{r}96 \\
104 \\
100 \\
97\end{array}$ & $\begin{array}{l}19.5 \\
17.0 \\
19.0 \\
17.5\end{array}$ \\
\hline Freeze-dried plasma .. & $\begin{array}{l}1.6 \\
2.4 \\
2.8 \\
3.2 \\
3.6 \\
4.0 \\
4.4 \\
4.8\end{array}$ & $\begin{array}{r}4 \\
6 \\
7 \\
8 \\
9 \\
10 \\
11 \\
12\end{array}$ & $\begin{array}{l}5.7 \\
5.6 \\
5.7 \\
5.6 \\
5.4 \\
5.7 \\
5.5 \\
5.6\end{array}$ & $\begin{array}{l}1.9 \\
2.1 \\
2 \cdot 2 \\
2 \cdot 2 \\
2.2 \\
2.4 \\
2.5 \\
2.6\end{array}$ & $\begin{array}{r}8.6 \\
8.9 \\
9.3 \\
9.3 \\
9.1 \\
9.8 \\
9.7 \\
10.1\end{array}$ & $\begin{array}{l}3.4 \\
3.4 \\
3.4 \\
3.4 \\
3.4 \\
3.6 \\
3.5 \\
3.5\end{array}$ & $\begin{array}{l}4.7 \\
4.4 \\
4.5 \\
4.6 \\
4.5 \\
4.9 \\
4.9 \\
4.9\end{array}$ & $\begin{array}{l}155 \\
155 \\
160 \\
155 \\
150 \\
160 \\
155 \\
160\end{array}$ & $\begin{array}{l}135 \\
137 \\
135 \\
138 \\
136 \\
133 \\
136 \\
134\end{array}$ & $\begin{array}{l}4.0 \\
4.0 \\
4.2 \\
4.2 \\
4.2 \\
4.4 \\
4.4 \\
4.5\end{array}$ & $\begin{array}{r}98 \\
102 \\
102 \\
99 \\
100 \\
101 \\
97 \\
99\end{array}$ & $\begin{array}{l}16 \cdot 5 \\
16 \cdot 0 \\
17.5 \\
16.5 \\
15.0 \\
19.0 \\
17.5 \\
20.5\end{array}$ \\
\hline Whole blood ... & $\begin{array}{l}5 \cdot 2 \\
5 \cdot 7\end{array}$ & $\begin{array}{l}13 \\
14\end{array}$ & $\begin{array}{l}5.4 \\
5 \cdot 4\end{array}$ & $\begin{array}{l}2 \cdot 5 \\
2 \cdot 6\end{array}$ & $\begin{array}{l}9.9 \\
9.9\end{array}$ & $\begin{array}{l}3.6 \\
3.8\end{array}$ & $\begin{array}{l}4.9 \\
4.9\end{array}$ & $\begin{array}{l}155 \\
155\end{array}$ & $\begin{array}{l}135 \\
136\end{array}$ & $\begin{array}{l}4 \cdot 4 \\
4 \cdot 5\end{array}$ & $\begin{array}{l}96 \\
96\end{array}$ & $\begin{array}{l}19 \cdot 0 \\
18.5\end{array}$ \\
\hline
\end{tabular}


a period of seven days while in hospital. The total protein concentration was reduced by $2.2 \mathrm{~g} / 100 \mathrm{ml}$ and returned to the original level in two weeks. The same patient then had 61 . of plasma exchanged with the IBM cell separator, reducing the plasma protein concentration by $4.0 \mathrm{~g} / 100 \mathrm{ml}$. The duration of the exchange was six hours and the benefit lasted three weeks. Similar rapid removal of abnormal protein is seen in a 47-yearold man with multiple myeloma (Case 8) in whom the paraprotein was a cryoglobulin. Abnormal protein was removed by conventional plasmapheresis and later by the IBM cell separator. In order to remove the same quantities of abnormal proteins by both procedures the IBM plasma exchange took only seven hours whereas the conventional procedure took five days.

In all patients studied in this series plasma containing abnormal protein was removed at the rate of about 11 ./hour and up to 81 . of plasma was removed at one session.

\section{COMPLICATIONS}

There are few complications during plasma exchange with the IBM cell separator. Mild shivering and nausea occur but are transient. Plasma exchange had to be discontinued once because the patient had a rigor, possibly resulting from the infusion of reconstituted freeze-dried plasma (this patient had minor rigors on three other occasions). On two occasions plasma exchange was stopped because the lubrication holes to the seal were blocked by abnormal protein, causing overheating of the seal and gelling of the protein in the tubes entering and leaving the centrifuge bowl.

On completion of a 6-1. plasma exchange in a patient with myeloma free haemoglobin was noticed in the plasma. This was due to blood being forced through clot to one of the filters. No ill effects were noted by the patient. Two instances may have been associated with hypocalcaemia.

\section{Discussion}

The medical indications for plasma exchange in patients with paraproteinaemia are the same as for conventional plasmapheresis, but plasma exchange has many advantages. The processing of large volumes of blood is rapid, simple, and safe. Clotting in the cannulae is rare because of the continuous flow of the patient's blood during separation. This is a notorious difficulty with conventional plasmapheresis, especially in macroglobulinaemia and cryglobulinaemia, often limiting the volume of plasma which can be removed.

The use of reconstituted freeze-dried plasma for plasma exchange has advantages for patients initially deficient in normal plasma constituents such as immunoglobulins or albumin. These deficiencies are corrected as the exchange approximates the composition of the patient's plasma to that of reconstituted freeze-dried plasma. Conventional plasmapheresis has an opposite effect. Kliman et al. (1964) showed that the removal of 51 . of plasma in five days in normal subjects caused a substantial decrease in both albumin and globulin concentrations and the depression of the gammaglobulins was of prolonged duration. These observations may be of importance as most patients with paraproteinaemia have lowered concentrations of normal immunoglobulins.

It is well known that plasmapheresis may stop haemorrhage in patients with paraproteinaemia. Solomon and Fahey (1963) arrested gastrointestinal haemorrhage in a patient with hyperglobulinaemia by the removal of 21 . of plasma. The IBM cell separator may have an advantage over plasmapheresis in stopping bleeding owing to its ability to supply some clotting factors present in freeze-dried plasma, in some of which the patient may be deficient. In this study bleeding from either the gums or nasopharynx usually ceased after the first litre of plasma had been exchanged in spite of the fact that the patient was receiving heparin.

Repeated plasmapheresis in patients with cryoglobulins in the blood may be of great clinical benefit. Solomon and Fahey (1963) showed improved tolerance to cold in cryglobulinaemia if the serum concentration of the abnormal protein was reduced by plasmapheresis, and this occurred even with relatively normal serum viscosities at body temperature. The problem of removing cryoglobulins, however, has become much simpler by using the IBM cell separator which can be kept at above $33^{\circ} \mathrm{C}$ with radiant heaters. The constant flow of the blood facilitates this effect.

For rapid reversal of neurological symptoms associated with the viscosity syndrome the IBM cell separator seems far superior to conventional plasmapheresis. Solomon and Fahey (1963) treated a patient with macroglobulinaemia having a generalized convulsive seizure by removal of 31 . of plasma over 30 hours. This stopped the seizures. Similarly, Mokeeva et al. (1966), in one case of macroglobulinaemia with precoma, showed pronounced improvement after about six days of plasmapheresis. With the IBM cell separator similar or better results were obtained more easily in a much shorter time.

A major theoretical disadvantage of using freeze-dried plasma is the possible transmission of viral hepatitis. So far there has been no clinical or biochemical evidence of hepatitis in any of the patients treated. A study is at present under way to see if the Australia antigen has appeared at any time during the treatment of these cases. Another disadvantage is the need to give anticoagulant drugs. During these investigations there was no morbidity which could be attributed to anticoagulation.

Clearly plasma exchange with a blood cell separator offers a definite advantage over regular plasmapheresis in the management of patients with paraproteinaemias.

This work was supported by grants from the Joseph Strong Frazer Trust, the Cancer Research Campaign, and the Medical Research Council. We thank Drs. P. E. Thompson Hancock and H. E. M. Kay for help in preparing this paper and Sir Ronald Bodley Scott, Professors E. B. Brown, J. R. Hobbs, and G. Wetherley-Mein, and Drs. J. P. Caplan, Pauline M. Emerson, D. J. Galton, G. B. Hollings, K. S. Kaplan, and Thomas Kramer for kindly referring patients included in the study. We also thank Misses Gwen Davies, Sheila Lynch, and Marie Huntly and Messrs. Ken Newton and Stanley Blake for technical help. We are indebted to the services of Drs. K. L. R. Rogers and J. V. Barry at the South London Regional Blood Transfusion Centre.

\section{References}

Buckner, D., Graw, R. G., Eisel, R. J., Henderson, E. S., and Perry, S. (1969). Blood, 33, 353

Conway, N., and Miles Walker, J. (1962). British Medical fournal, 2, 1296. Godal, H. C., and Borchgrevink, C. F. (1965). Scandinavian fournal of Clinical and Laboratory Investigation, 17, Supplement No. 84, 133.

Kliman, A., Carbone, P. P., Gaydos, L. A., and Freireich, E. J. (1964). Blood, 23, 647 .

Lawson, N. S., Nosanchuk, J. S., Oberman, H. A., and Meyers, M. C. (1968). Transfusion, 8, 174.

Mokeeva, R. A., et al. (1966). Federation Proceedings (Translation Supplement), 25, 153.

Powles, R. L., Balchin, L. A., Hamilton Fairley, G., and Alexander, P. (1971). British Medical fournal, 1, 486.

Schwab, P. J., and Fahey, J. L. (1960). New England fournal of Medicine, 263, 574 .

Skoog, W. A., Adams, W. S., and Coburn, J. W. (1962). Blood, 19, 425. Solomon, A., and Fahey, J. L. (1963). Annals of Internal Medicine, 58, 789 . 